\title{
Distribution and recombination of Wolbachia endosymbionts in Korean coleopteran insects
}

\author{
Gilsang Jeong ${ }^{1 *} \mathbb{D}$, Taeman Han², Haechul Park², Soyeon Park ${ }^{3}$ and Pureum Noh ${ }^{4}$
}

\begin{abstract}
Background: Wolbachia are among the most prevalent endosymbiotic bacteria and induce reproductive anomalies in various invertebrate taxa. The bacterium has huge impacts on host reproductive biology, immunity, evolution, and molecular machinery. However, broad-scale surveys of Wolbachia infections at the order scale, including the order Coleoptera, are limited. In this study, we investigated the Wolbachia infection frequency in 201 Coleopteran insects collected in Korea.

Results: A total of 26 species (12.8\%) belonging to 11 families harbored Wolbachia. The phylogenetic trees of based on partial 165 rRNA gene sequences and partial Wolbachia surface protein (wsp) gene sequences were largely incongruent to that of their hosts. This result confirms that Wolbachia evolved independently from their hosts,

Conclusion: Phylogenetic trees suggest that complex horizontal gene transfer and recombination events occurred within and between divergent Wolbachia subgroups.
\end{abstract}

Keywords: Horizontal gene transfer, Recombination, Wolbachia

\section{Background}

Wolbachia are highly prevalent endosymbiotic bacteria known to induce reproductive anomalies, such as cytoplasmic incompatibility, feminization, male-killing, and parthenogenesis, in various arthropod species, nematodes, isopods, and mites (Stouthamer et al. 1997, Werren and Windsor 2000; Zug and Hammerstein 2012). Bacteria in the genus have major impacts on host reproductive biology, immunity, evolution, and molecular machinery. Despite the controversy over the taxonomic status, the prevailing view is that Wolbachia in various hosts should be considered a single species divided into 14 supergroups (Glowska et al. 2015; Lindsey et al. 2016; Lo et al. 2002; Ramírez-Puebla et al. 2016). The genus has been a focus of research owing to its potential to control host populations, especially mosquito populations, by artificially infecting cytoplasmic incompatibility-inducing strains (Bourtzis et al. 2014; Werren 2008; Xi et al. 2006). Recent success in field trials has provided a new and safe

\footnotetext{
*Correspondence: ecodever@gmail.com; gilsangj@nie.re.kr

'Long Term Ecological Research Team, National Institute of Ecology,

Seocheon 33657, Republic of Korea

Full list of author information is available at the end of the article
}

approach for the control of Aedes aegypti, a vector of fatal viruses, such as dengue, Zika, and chikungunya (O'Neill 2016; O'Neill et al. 2018). Similar approaches for control are not necessarily limited to mosquito species but can be applied to virtually any host pest (Rostami et al. 2016).

Despite its ecological and evolutionary importance and application, in Korea, infection surveys of the bacterium have been limited to specific taxa (Choi et al. 2015; Jeong et al. 2009a and b; Jeong et al. 2012; Park et al. 2016). Since the order, Coleoptera is the largest group of insects and includes pest species affecting economic activity in Korea (see Moon and Lee 2015), we determined to investigate the Wolbachia infection frequency in the insects collected in Korea.

To our knowledge, this is the first intensive survey of Wolbachia infection at the order level in Korea.

\section{Results and discussion Wolbachia infection frequency}

In the survey, 26 out of 201 coleopteran species were infected with Wolbachia and the genes are annotated (Tables 1 and 2, and Additional file 1: Table S1). Among 27 families, we detected Wolbachia in 10. For 18 families, we 
Table 1 Infection frequency at the family level

\begin{tabular}{|c|c|c|c|c|}
\hline Number & Family & No. species & Infected & $\%$ infection \\
\hline 1 & Carabidae & 24 & 2 & 8.3 \\
\hline 2 & Dytiscidae & 4 & 0 & 0.0 \\
\hline 3 & Hydrophilidae & 2 & 0 & 0.0 \\
\hline 4 & Histeridae & 2 & 0 & 0.0 \\
\hline 5 & Silphidae & 2 & 0 & 0.0 \\
\hline 6 & Staphylinidae & 2 & 0 & 0.0 \\
\hline 7 & Lucanidae & 4 & 0 & 0.0 \\
\hline 8 & Scarabaeidae & 26 & 0 & 0.0 \\
\hline 9 & Psephenidae & 1 & 1 & 100.0 \\
\hline 10 & Buprestidae & 4 & 0 & 0.0 \\
\hline 11 & Melyridae & 1 & 0 & 0.0 \\
\hline 12 & Nitidulidae & 1 & 0 & 0.0 \\
\hline 13 & Languriidae & 2 & 1 & 50.0 \\
\hline 14 & Byturidae & 1 & 1 & 100.0 \\
\hline 15 & Endomychidae & 1 & 1 & 100.0 \\
\hline 16 & Tenebrionidae & 14 & 0 & 0.0 \\
\hline 17 & Coccinellidae & 13 & 0 & 0.0 \\
\hline 18 & Oedemeridae & 7 & 1 & 14.3 \\
\hline 19 & Stenotrachelidae & 1 & 0 & 0.0 \\
\hline 20 & Meloidae & 1 & 0 & 0.0 \\
\hline 21 & Anthicidae & 2 & 0 & 0.0 \\
\hline 22 & Cerambycidae & 21 & 2 & 9.5 \\
\hline 23 & Chrysomelidae & 39 & 10 & 25.6 \\
\hline 24 & Athribidae & 1 & 0 & 0.0 \\
\hline 25 & Attelabidae & 9 & 4 & 44.4 \\
\hline 26 & Apionidae & 1 & 1 & 100.0 \\
\hline \multirow[t]{2}{*}{27} & Curculionidae & 15 & 2 & 13.3 \\
\hline & Total & 201 & 26 & 12.9 \\
\hline
\end{tabular}

examined fewer than 4 species. Among families for which at least 5 species were examined, Attelabidae showed the highest infection frequency (4 out of 9 species), followed by Oedemeridae ( 1 out of 7 species), Chrysomelidae (10 out of 39 species), and Curculionidae (2 out of 15 species) (Table 1). On the other extreme, infection was not detected in any Carabidae samples. Recent two in-depth reviews show that the Wolbachia infection frequency in beetle species is about 38\% and $27 \%$ respectively (Kajtoch et al. 2019; Kajtoch and Kotásková 2018). In our analysis, only $12.9 \%$ of beetle species harbored the bacterium. This discrepancy may be explained by a difference in the sampling method. Since we examined a single specimen per species, partial infections within populations were not resolved. Further tests should include multiple specimens for each species. All gene sequences named after the host insect species were deposited at GenBank and the
Table 2 Annotation of Wolbachia from beetle species

\begin{tabular}{|c|c|c|c|}
\hline Genus & Family & $16 \mathrm{~s}$ & wsp \\
\hline Colpodes buchanani & Carabidae & sCbu & wCbu \\
\hline Dicranoncus femoralis & Carabidae & sDfe & wDfe \\
\hline Eubrianax granicollis & Psephenidae & sEgr & wEgr \\
\hline \multirow[t]{5}{*}{ Anadastus praeustus } & Languriidae & sApr & WApr1 \\
\hline & Languriidae & & wApr2 \\
\hline & Languriidae & & wApr3 \\
\hline & Languriidae & & wApr4 \\
\hline & Languriidae & & wApr5 \\
\hline Byturus aestivus & Byturidae & sBae & wBae \\
\hline Ancylopus pictus & Endomychidae & sApi & WApi \\
\hline Oedemeronia lucidicolis & Oedemeridae & sOlu & wOlu \\
\hline Pogonocherus seminiveus & Cerambycidae & sPse & wPse \\
\hline Rhaphuma diminuta & Cerambycidae & sRdi & wRdi \\
\hline Aulacophora indica & Chrysomelidae & sAin & WAin \\
\hline Basilepta pallidula & Chrysomelidae & sBpa & wBpa \\
\hline Monolepta shirozui & Chrysomelidae & sMsh & wMsh \\
\hline Lema diversa & Chrysomelidae & sLdi & wLdi \\
\hline Medythia nigrobilineata & Chrysomelidae & sMni & wMni \\
\hline Smaragdina semiaurantiaca & Chrysomelidae & sSse & wSse1 \\
\hline Aulacophora nigripennis & Chrysomelidae & sAni & wAni1 \\
\hline Aspidomorpha transparipennis & Chrysomelidae & sAtr & wAtr \\
\hline Gallerucida bifasciata & Chrysomelidae & sGbi & wGbi \\
\hline \multirow[t]{3}{*}{ Agelasa nigriceps } & Chrysomelidae & sAnig & WAnig \\
\hline & Chrysomelidae & & wSse2 \\
\hline & Chrysomelidae & & wAni2 \\
\hline Euops lespedezae & Attelabidae & sEle & wEle \\
\hline Paracycnotrachelus longiceps & Attelabidae & sPlo & wPlo \\
\hline Cycnotrachelus coloratus & Attelabidae & sCco & wCco \\
\hline Byctiscus venustus & Attelabidae & sBve & wBve \\
\hline Apion collare & Brenthidae & sAco & WAco \\
\hline Baris dispilota & Culculionidae & sBdi & wBdi \\
\hline Lixus maculatus & Culculionidae & sLma1 & wLma1 \\
\hline
\end{tabular}

accession numbers are in Table 2 and Additional file 1: Table S1. There have been studies on the Wolbachia infection status in various coleopteran insects (Werren et al. 1995; Kajtoch and Kotásková 2018). Incongruence in infection frequency from them may be caused by geographical variation and taxonomic composition.

\section{Phylogeny of Wolbachia}

Phylogenetic trees based on 16S rRNA and wsp were largely incongruent (Fig. 1). This result confirms that Wolbachia evolved independently from their hosts, as indicated by Kajtoch and Kotásková (2018). 


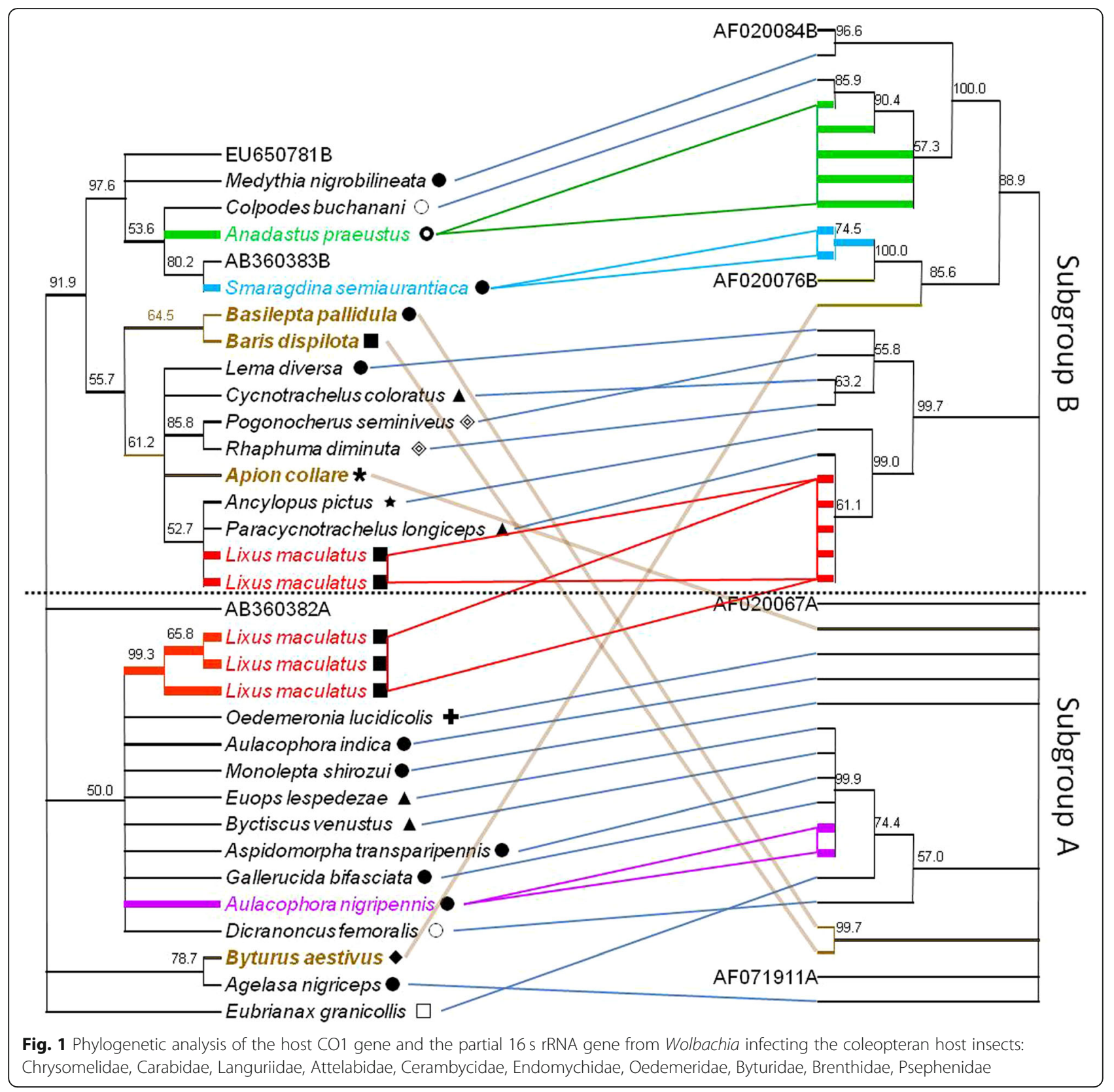

Interestingly, some species, such as Lixus maculates, were superinfected with 5 strains of Wolbachia. These strains likely diverged after a single infection, as evidenced by the monophyletic clustering of each gene (Fig. 2). However, Anadastus praeustus, Smaragdina semiaurantiaca, and Aulacophora nigripennis were superinfected based only on wsp gene diversity. For Wolbachia-infecting Basilepta pallidula, Baris dispilota, Apion collare, and Byturus aestivus, we detected incongruence between $16 \mathrm{~S}$ rRNA and wsp phylogenies, as observed for Byturus unicolor in this study (Fig. 2). This finding indicates that the genes evolved independently.
The Wolbachia strain in Anadastus praeustus showed five $w s p$ alleles. This can potentially be explained by synonymous substitutions in $16 \mathrm{~S}$ rRNA and $w s p$, rather than by recombination (data not shown). Wolbachia strains infecting Lixus maculates told a different story. The $16 \mathrm{~S}$ rRNA gene of Wolbachia-infecting Lixus maculatus could be assigned to two main subgroups (three in subgroup A and two in B). However, the wsp sequences exhibited high similarity and were all assigned to subgroup A (Fig. 2). This implies that strains in the two subgroups infected the host and accumulated synonymous substitutions after recombination. Under the assumption that the $16 \mathrm{~S}$ rRNA 


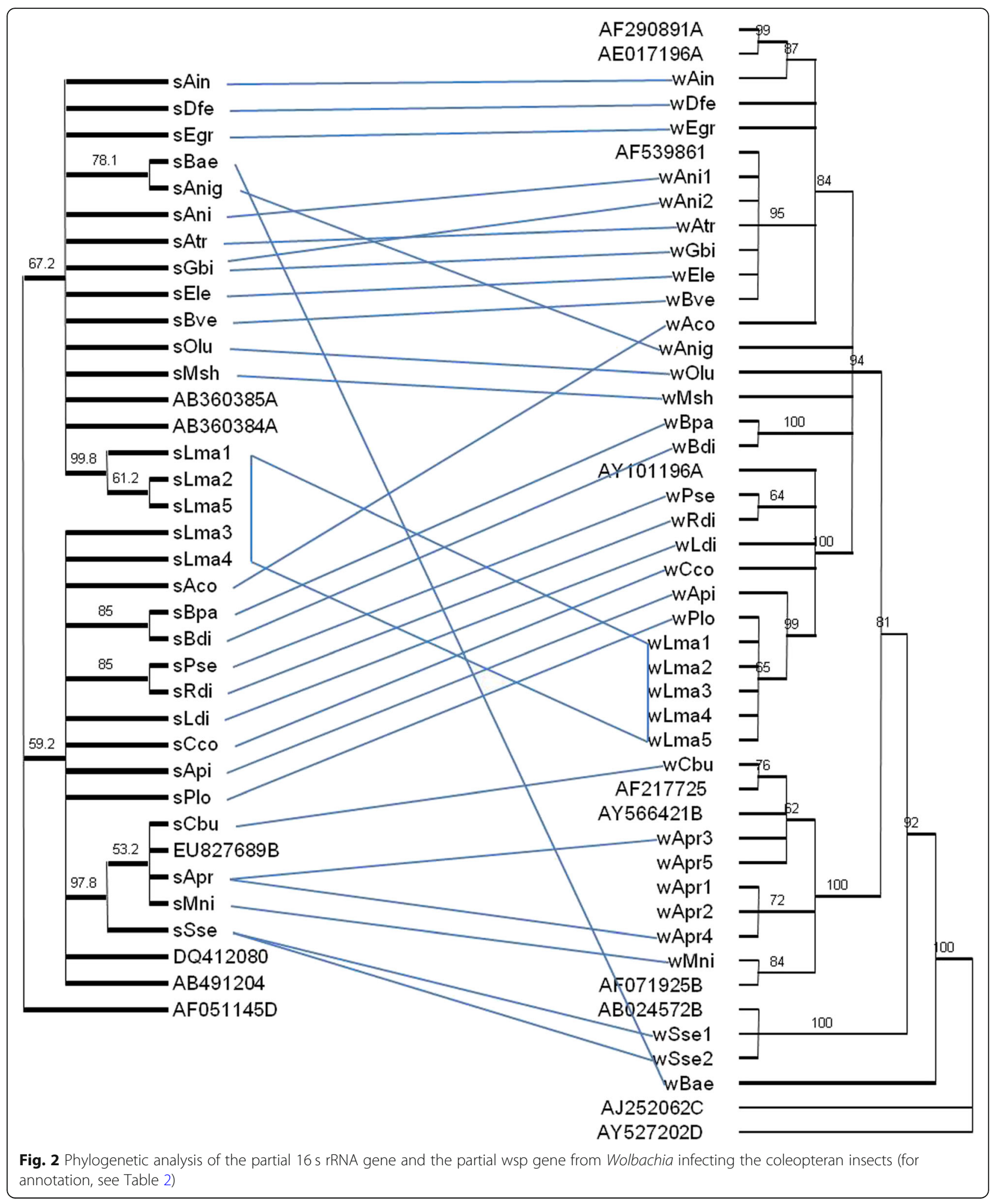

and wsp phylogenies are strictly congruent, strains that acquired $w s p$ of subgroup B were selected against. Since the two genes are functional, this suggests that the strain with $w s p$ classified as subgroup A has deleterious mutations in essential genes other than wsp. Another less likely explanation is that these strains were simply lost due to drift with no sex ratio drive; however, this does not explain how only particular strains were affected. Previously Wolbachia was 
suspected to induce parthenogenesis and oocyte formation in the host species (Chen et al. 2012; Rodriguero et al. 2010; Son et al. 2008). However, we were unable to infer the effect of infection on hosts' life history due to the lack of general biology of the Korean coleopteran insects.

\section{Conclusions}

In this study, $12.8 \%$ of Korean beetle species are infected with Wolbachia. Phylogenetic trees suggest that complex horizontal gene transfer and recombination events occurred within and between divergent Wolbachia subgroups resulting in largely incongruent phylogenetic relationships.

\section{Materials and methods Study materials}

Coleopteran species were mostly collected by light trapping at night between May and August 2008 in various locations in South Korea (Additional file 1: Table S1). They were brought into the laboratory and identified carefully. Voucher specimens were deposited at the NAAS repository. Genomic DNA was extracted from a leg of the specimens using the DNeasy Mini Kit (Qiagen, Hilden, Germany) or the AccuPrep ${ }^{\circ}$ Genomic DNA Extraction Kit (Bioneer, Daejeon, Korea) and stored at $-80^{\circ} \mathrm{C}$ until use.

\section{Determination of Wolbachia infection}

All PCRs were performed using a total volume of $20 \mu \mathrm{l}$ in AccuPower PCR PreMix (Bioneer) and a thermocycler (Biometra, Tubingen, Germany).

The quality of genomic DNA was determined by PCR using a universal arthropod 28S rRNA primer set (forward: TAC CGT GAG GGA AAG TTG AAA and reverse: AGA CTC CTT GGT CCG TGT TT) or a universal CO1 primer set (forward: GGT CAA CAA ATC ATA AAG ATA TTG $G$ and reverse: TAA ACT TCA GGG TGA CCA AAA AAT CA) (Jeong et al. 2009a, 2009b). The temperature profile for $28 \mathrm{~S}$ rRNA diagnostic PCR was $2 \mathrm{~min}$ of predenaturation at $94{ }^{\circ} \mathrm{C}$, followed by 38 cycles of $30 \mathrm{~s}$ at $94{ }^{\circ} \mathrm{C}$, $50 \mathrm{~s}$ at $58^{\circ} \mathrm{C}, 90 \mathrm{~s}$ at $72^{\circ} \mathrm{C}$, and a final extension for $10 \mathrm{~min}$ at $72^{\circ} \mathrm{C}$.

A Wolbachia-diagnostic marker (forward: CAT ACC TAT TCG AAG GGA TAG and reverse: AGC TTC GAG TGA AAC CAA TTC) was used to determine the infection status of specimens. Genomic DNA of Wolbachia-infected Cadra cautella (Pyralidae: Lepidoptera) was used as a positive control. The temperature profile for Wolbachiaspecific diagnostic PCR was $2 \mathrm{~min}$ of pre-denaturation at $94^{\circ} \mathrm{C}$, followed by 38 cycles of $30 \mathrm{~s}$ at $94^{\circ} \mathrm{C}, 45 \mathrm{~s}$ at $55^{\circ} \mathrm{C}$, $90 \mathrm{~s}$ at $72^{\circ} \mathrm{C}$, and a final extension for $10 \mathrm{~min}$ at $72^{\circ} \mathrm{C}$.

Positive PCR samples for $28 \mathrm{~S}$ rRNA and/or CO1 and the Wolbachia diagnostic marker were scored as infected. Additionally, when a sample was negative for $28 \mathrm{~S}$ rRNA and/or CO1 but positive for the Wolbachia marker, the species was scored as infected.

\section{Genotyping of Wolbachia}

Multilocus sequence typing (MLST) is widely used for genotyping and assignment to supergroups in Wolbachia (Baldo et al. 2006; but see Bleidorn and Gerth 2017). The MLST was not adopted since this study was a basic survey on Wolbachia from Korean Coleopteran insects. Instead, we chose two conventionally used genes. For samples identified as infected, PCR was performed with genomic DNA to obtain the partial 16S rRNA gene sequence and partial Wolbachia surface protein (wsp) gene sequence. For Wolbachia, nested PCR was performed following the methods described by Weeks et al. (2003). For the initial PCR, the 16S rDNA primer set was used (27f and 1513r) (Weisburg et al., 1991). The temperature profile was 4 min of pre-denaturation at $94^{\circ} \mathrm{C}$, followed by 35 cycles of $1 \mathrm{~min}$ at $94^{\circ} \mathrm{C}, 1 \mathrm{~min}$ at $52^{\circ} \mathrm{C}$, and $1 \mathrm{~min}$ at $72^{\circ} \mathrm{C}$, and a final extension for $5 \mathrm{~min}$ at $72^{\circ} \mathrm{C}$. Then, Wolbachia-specific PCR was performed using the Wolbachia-specific 16S rDNA primer set (176f and 1012r) taken from O'Neill et al. (1992). One microliter of initial PCR product was diluted 10 -fold and used as template DNA. The temperature profile for PCR was $4 \mathrm{~min}$ of pre-denaturation at $94{ }^{\circ} \mathrm{C}$, followed by 35 cycles of $1 \mathrm{~min}$ at $94^{\circ} \mathrm{C}, 1 \mathrm{~min}$ at $50^{\circ} \mathrm{C}$, and $1 \mathrm{~min}$ at $72^{\circ} \mathrm{C}$, and a final extension for $5 \mathrm{~min}$ at $72^{\circ} \mathrm{C}$. The partial wsp gene of the bacterium was obtained using the following primer set: 81f, TGG TCC AAT AAG TGA TGA AGA AAC; 691r, AAA AAT TAA ACG CTA CTC CA (Zhou et al. 1998). The temperature profile was $5 \mathrm{~min}$ of pre-denaturation at $94^{\circ} \mathrm{C}$, followed by 35 cycles of 1 min at $94^{\circ} \mathrm{C}, 1 \mathrm{~min}$ at $55^{\circ} \mathrm{C}$, and $1 \mathrm{~min}$ at $72^{\circ} \mathrm{C}$, and a final extension for $5 \mathrm{~min}$ at $72^{\circ} \mathrm{C}$.

\section{Phylogenetic analyses}

A multiple sequence alignment of all partial 16S rRNA genes and wsp genes from Wolbachia was generated using ClustalW embedded in MEGA (ver. 6, Tamura et al. 2013). The protein-coding $w s p$ gene sequences were translated into amino acid sequences before alignment. These sequences were then reverse-translated into DNA sequences.

The alignments were manually adjusted. All gaps were manually removed, resulting in $765 \mathrm{bp}$ of the partial $16 \mathrm{~S}$ rRNA gene, of which 31 sites were parsimony-informative, and $509 \mathrm{bp}$ of wsp, of which 172 sites were parsimonyinformative. The HKY + I and TVM + I + G models of evolution were used to estimate phylogenies for 16S rRNA and the $w s p$, respectively, the best-fit models were determined by log-likelihood ratio tests using ModelTest (ver. 3.7, Posada and Crandall 1998).

Likelihood analyses were performed using PAUP* (ver. 4.0b, Swofford 2002) by a heuristic search with 10,000 random sequence replicates and the tree-bisectionreconnection branch swapping algorithm. Nodal support was estimated using 500 bootstrap replicates with 10 random addition sequence replicates per bootstrap replicate. 
The phylogenetic trees were visualized and manually edited using TreeGraph 2 (Müller and Müller 2004).

\section{Supplementary information}

Supplementary information accompanies this paper at https://doi.org/10. 1186/s41610-019-0143-2

Additional file 1. Information on the beetle insect samples used for this study with infection status.

\section{Abbreviations}

COI: Cytochrome oxidase I; PCR: Polymerase chain reaction; rDNA: Ribosomal DNA; rRNA: Ribosomal RNA; wsp: Wolbachia surface protein

\section{Acknowledgements}

This study is supported by long-term ecological research (NIE-Strategic Research-2019-02). The authors deeply thank many anonymous collectors who helped to collect the insects.

\section{Authors' contributions}

GJ designed the study. TMH and HCP collected the samples in the field. GJ, SP, and PN analyzed the data and wrote the manuscript. SSK reviewed the manuscript. All authors read and approved the final manuscript.

\section{Funding}

The study was supported by the National Institute of Ecology fund (no: NIEStrategic Research-2019-02).

\section{Availability of data and materials}

The sequence data can freely be obtained from NCBI. The datasets generated during and/or analyzed during the current study are available from the corresponding author on reasonable request.

\section{Ethics approval and consent to participate}

Not applicable.

\section{Consent for publication}

Not applicable.

\section{Competing interests}

The authors declare that they have no competing interests.

\section{Author details}

${ }^{1}$ Long Term Ecological Research Team, National Institute of Ecology, Seocheon 33657, Republic of Korea. 'Department of Agricultural Biology, National Academy of Agricultural Science, RDA, Jeonju-si, Republic of Korea. ${ }^{3}$ Evolutionary Ecology Research Team, National Institute of Ecology, Seocheon 33657, Republic of Korea. ${ }^{4}$ Herbal Medicine Resources Research Center, Korea Institute of Oriental Medicine, Naju 58245, Republic of Korea.

Received: 10 October 2019 Accepted: 5 December 2019

Published online: 19 December 2019

\section{References}

Baldo L, Hotopp JC, Jolley KA, Bordenstein SR, Biber SA, Choudhury RR, Hayashi C, Maiden MC, Tettelin H, Werren JH. Multilocus sequence typing system for the endosymbiont Wolbachia pipientis. Appl Environ Microbiol. 2006;72(11):7098-110.

Bleidorn C, Gerth M. A critical re-evaluation of multilocus sequence typing (MLST) efforts in Wolbachia. FEMS Microbiol Ecol. 2017;94(1):fix163.

Bourtzis K, Dobson SL, Xi Z, Rasgon JL, Calvitti M, Moreira LA, Bossin HC, Moretti R, Baton LA, Hughes GL, Mavingui P. Harnessing mosquito-Wolbachia symbiosis for vector and disease control. Acta Trop. 2014;132:S150-63.

Chen SJ, Lu F, Cheng JA, Jiang MX, Way MO. Identification and biological role of the endosymbionts Wolbachia in rice water weevil (Coleoptera: Curculionidae). Environl Entomol. 2012;41(3):469-77.

Choi S, Shin SK, Jeong G, Yi H. Wolbachia sequence typing in butterflies using pyrosequencing. J Microbiol Biotechnol. 2015;25(9):1410-6.

Glowska E, Dragun-Damian A, Dabert M, Gerth M. New Wolbachia supergroups detected in quill mites (Acari: Syringophilidae). Infect Genet Evol. 2015;30:140-6.
Jeong G, Ahn J, Jang Y, Choe JC, Choi H. Wolbachia infection in the Loxoblemmus complex (Orthoptera: Gryllidae) in Korea. J Asia Pac Entomol. 2012;15(4):563-6.

Jeong G, Kang T, Park H, Choi J, Hwang S, Kim W, Choi Y, Lee K, Park I, Sim H, Kim J. Wolbachia infection in the Korean endemic firefly, Luciola unmunsana (Coleoptera: Lampyridae). J Asia Pac Entomol. 2009a;12(1):33-6.

Jeong G, Lee K, Choi J, Hwang S, Park B, Kim W, Choi Y, Park I, Kim J. Incidence of Wolbachia and Cardinium endosymbionts in the Osmia community in Korea. J Microbiol. 2009b;47(1):28.

Kajtoch Ł, Kolasa M, Kubisz D, Gutowski JM, Ścibior R, Mazur MA, Holecová M. Using host species traits to understand the Wolbachia infection distribution across terrestrial beetles. Sci Rep. 2019;9(1):847.

Kajtoch $Ł$, Kotásková N. Current state of knowledge on Wolbachia infection among Coleoptera: a systematic review. PeerJ. 2018;9(6):e4471.

Lindsey AR, Bordenstein SR, Newton IL, Rasgon JL. Wolbachia pipientis should not be split into multiple species: A response to Ramírez-Puebla et al.,"Species in Wolbachia? Proposal for the designation of 'Candidatus Wolbachia bourtzisii,',Candidatus Wolbachia onchocercicola,'Candidatus Wolbachia blaxteri','Candidatus Wolbachia brugii','Candidatus Wolbachia taylori,',Candidatus Wolbachia collembolicola'and 'Candidatus Wolbachia multihospitum' for the different species within Wolbachia supergroups". Syst Appl Microbiol. 2016;39(3):220

Lo N, Casiraghi M, Salati E, Bazzocchi C, Bandi C. How many Wolbachia supergroups exist? Mol Biol Evol. 2002;19(3):341-6.

Moon S, Lee S. Diseases and insect pests of woody plants. Nat Ecol. 2015;Seoul:879.

Müller J, Müller K. TreeGraph: automated drawing of complex tree figures using an extensible tree description format. Mol Ecol Notes. 2004;4(4):786-8.

O'Neill SL. Wolbachia mosquito control: Tested. Science. 2016;352(6285):526.

O'Neill SL, Ryan PA, Turley AP, Wilson G, Retzki K, Iturbe-Ormaetxe I, Dong Y, Kenny N, Paton CJ, Ritchie SA, Brown-Kenyon J. Scaled deployment of Wolbachia to protect the community from dengue and other Aedes transmitted arboviruses. Gates Open Res. 2018;1:2

Park CH, Lim H, Kim H, Lee WG, Roh JY, Park MY, Shin EH. High prevalence of Wolbachia infection in Korean populations of Aedes albopictus (Diptera: Culicidae). J Asia Pac Entomol. 2016;19(1):191-4.

Posada D, Crandall KA. Modeltest: testing the model of DNA substitution. Bioinformatics. 1998;14(9):817-8.

Rodriguero MS, Confalonieri VA, Guedes JV, Lanteri AA. Wolbachia infection in the tribe Naupactini (Coleoptera, Curculionidae): association between thelytokous parthenogenesis and infection status. Insect Mol Biol. 2010;19(5):631-40.

Rostami E, Madadi H, Abbasipour H, Sivaramakrishnan S. Wolbachia-mediated reproductive alterations in arthropod hosts and its use for biocontrol program. Korean J Appl Entomol. 2016;55(2):177-88.

Son Y, Luckhart S, Zhang X, Lieber MJ, Lewis EE. Effects and implications of antibiotic treatment on Wolbachia-infected vine weevil (Coleoptera: Curculionidae). Agr Forest Entomol. 2008;10(2):147-55.

Swofford DL. PAUP*. Phylogenetic analysis using parsimony (*and other methods). Sunderland: Sinauer Associates; 2002. ver. 4.10b.

Tamura K, Stecher G, Peterson D, Filipski A, Kumar S. MEGA6: molecular evolutionary genetics analysis version 6.0. Mol Biol Evol. 2013;30(12):2725-9.

Werren JH, Windsor D, Guo LR. Distribution of Wolbachia among neotropical arthropods. P Roy Soc Lond B Bio. 1995;262(1364):197-204.

Werren $\mathrm{JH}$, Windsor DM. Wolbachia infection frequencies in insects: evidence of a global equilibrium? P Roy Soc Lond B Bio. 2000;267(1450):1277-85.

Xi Z, Khoo CC, Dobson SL. Interspecific transfer of Wolbachia into the mosquito disease vector Aedes albopictus. P Roy Soc Lond B Bio. 2006;273(1592):1317-22.

Zug R, Hammerstein P. Still a host of hosts for Wolbachia: analysis of recent data suggests that $40 \%$ of terrestrial arthropod species are infected. PLoS One. 2012;7(6):e38544

\section{Publisher's Note}

Springer Nature remains neutral with regard to jurisdictional claims in published maps and institutional affiliations. 